\title{
Parody Iklan, Meningkatkan Brand Awaraness melalui Olokan
}

\author{
$\underline{\text { Aulia Suminar Ayu }}$ \\ Magister Ilmu Komunikasi \\ Universitas Diponegoro \\ aulia.sumi@gmail.com
}

\begin{abstract}
Usually, parody were used to show how audience dislike or resistance with certain texts. Recently, parody about the standarized herbal product, "Mastin" were circulating around social media world. This phenomenon starts from Mastin parody video on youtube. Repetitive use of Mastin' TVC lyrics, "kabar gembira untuk kita semua" was becoming new joke trend and slang on cyber and real world. On the other side, that was insulting and making people bored of that kind of joke. Either do Mastin, along with this trend, Mastin changes their TVC Jingle chord (until) three times in order to make audience didn't get drown on boredom. This text would be explained by reception analysis as methodology with Elaboration Likelihood Modes and Hirearchy of Effect Model as theoritical background. Subject of this research are people who reviewing Mastin on their webblog, and Mastin user that researcher met on real world. This study aimed to understand how audiences interpret Mastin related with this parody.
\end{abstract}

Keyword: Parody, Mastin, Audience Reception Analysis, Elaboration Likelihood Model, Hirearchy of Effect Model

\section{Pendahuluan}

Humor dapat diklasifikasikan sebagai segala tindakan yang dapat memancing gelak tawa. Humor dapat menjadi hal yang lucu, atau justru menyinggung. Apabila dikaji secara kritis, suatu hal yang dianggaplucu adalah hal yang tidak wajar dan aneh sehingga terkadang menyakiti perasaan orang lain. Terdapat perbedaan latar belakang sosiologis dan psikologis setiap orang saat menerima suatu candaan, selayaknya istilah "as one man's mear is another man's poison" (Palmer, 1994: 177), jadi lelucon yang dilontarkan oleh seseorang, dapat bersifat ofensif bagi orang lain atau memicu bored incomprehension atau dalam bahasa informal sehari-hari lebih dikenal "garing" karena ketidakpahaman dan ketidaknyamanan seseorang akan lelucon.

Pada umumnya, parodi pada periklanan digunakan sebagai cara untuk menciptakan pesan iklan yang lucu. Tujuan utama dari parodi dalam iklan adalah penggunaan humor unuk menngkatkan brand evaluation (positive attitude), recall, dan recognition (Jean, 2011 dalam Lou dan Wang, 2015: 11). Dualisme parodi yang dapat berfungsi sebagai humor atau permainan jenaka atau sebagai bentuk penghinaan atau olok-olok memang sulit dibedakan satu sama lainnya. Terdapat berbagai macam iklan parodi, salah satunya adalah serangan parodi (parody attack). Serangan parodi dapat dilakukan dengan cara mengubah karakteristik (kata-kata atau gambar) yang ada dalam iklan yang asli. Serangan parodi terhadap iklan dapat berasal dari kompetitor, organisasi non-profit anti mainstream seperti Adbuster Media Foundation di Kanada, organisasi anti komersial, atau justru pengguna internet yang dapat menjatuhkan sikap positif konsumen terhadap merk suatu produk. Tujuan utama dari serangan parodi adalah untuk menunjukkan keburukan suatu produk, mengolok-olok konsumen merk tertentu, dan menjatuhkan reputasi dari merk yang terdepan. 
Sejak tahun 2000-an awal, penetrasi internet di Indonesia terus meningkat. Meningkatnya penetrasi internet ini mengubah cara pandang masyarakat dalam mencari informasi. Masyarakat menjadi pengguna aktif yang menyeleksi kanal-kanal seperti apa yang diinginkan untuk dikonsumsi sesuai kebutuhan dan keinginan mereka melalui internet. Menjamurnya forum-forum internet serta media sosial seperti blog, facebook, path, twitter, kaskus, instagram mengubah cara interaksi dan saling bertukar informasi. Jika sebelumnya istilah pemasaran WOM (Word of Mouth) merupakan suatu penyebaran akibat diskusi dari "mulut-kemulut", maka kini konsepnya berubah menjadi dari media sosial ke media sosial.

Apabila ada suatu hal yang dianggap, beritanya akan cepat tersebar melalui dunia maya (terutama media sosial dan forum internet). Kondisi ini dapat memberikan pengaruh pada suatu produk apabila terdapat ulasan yang buruk dari netizen, dan dapat menjatuhkan citra produk mereka. Begitu pula hal yang sebaliknya. Bila dimanfaatkan secara baik dapat digunakan sebagai promosi cuma-cuma bagi produk terkait. Pengaruh ini disebut dengan efek word of mouth atau viral. Menyebarkan informasi layaknya virus yang menularkan penyakit.

Di Indonesia, terdapat parodi iklan yang menyebar secara viral di dunia sosial media (Facebook, Twitter, Path) dalam berbagai macam bentuk mulai dari video, meme, hingga menjadi bahasa pergaulan (slang) sehari-hari. Produk itu adalah Mastin, obat herbal terstandar berupa ekstrak kulit manggis.

Popularitas parodi iklan Mastin dapat tergambarkan dari angka-angka berikut ini (Kurniawan, 2015: 7), bahwa terdapat 54.600 halaman web yang membicarakan iklan Mastin, pada hasil pencarian www.google.com dengan kata kunci "iklan Mastin" (pencarian termasuk dengan tanda petik). Pada situs video-sharing terpopuler di dunia www.youtube.com, pencarian dengan kata kunci yang sama memberikan hasil
18.400 video berkaitan dengan mastin baik itu berupa video asli hasil capture dari siaran televisi, liputan maupun parodinya. Pada forum maya lokal terbesar di Indonesia www.kaskus. co.id, terdapat 3090 thread yang membicarakan iklan Mastin. Hasil ini menunjukkan netizen Indonesia memberikan respon yang luar biasa mengingat Mastin hanyalah sebuah tayangan iklan.

Singkat kata, parodi iklan Mastin menjadi melekat dalam masyarakat dan penggunaan lirik "kabar gembira untuk kita semua" menjadi sebuah lelucon dan bahasa sehari-hari. Penggunaan kata-kata yang repetitif ini pada suatu saat menimbulkan suatu kejenuhan dan menjadi lelucon garing yang menjengkelkan. Kejengkelan itu nampak pada beberapa halaman facebook akun resmi seperti Intel Indonesia, dan Mario Teguh yang sampai mengeluarkan pernyataan bahwa akan memblokir akun yang menggunakan lelucon kabar gembira dalam komentar pada akun mereka. Bahkan Juki, komikus kenamaan dunia maya juga sampai mengeluarkan parodi tandingan (counterparody) betapa kesalnya dirinya pada lelucon tersebut.

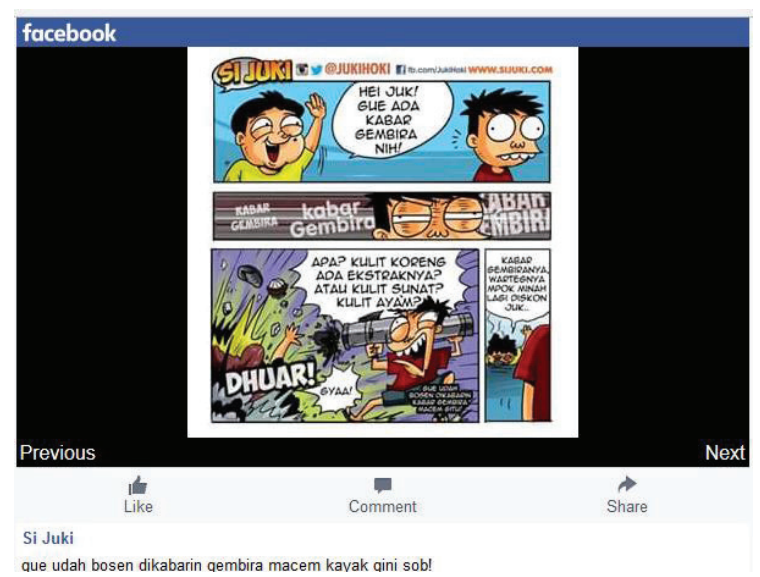

Gambar 1.1. Counter Parody dari- Parodi Iklan Mastin $^{1}$

Pada umumnya, merk produk-produk jamu dan obat herbal terstandar sulit untuk memiliki tempat di benak masyarakat. Namun hal yang 
berbeda justru terjadi pada produk ekstrak kulit manggis dari PT. Industri Jamu Borobudur, Semarang. Mastin justru menjadi perbincangan oleh khalayak luas akibat dari maraknya parodi dan iklannya.

Oleh karena itu, peneliti ingin memahami bagaimana audiens memaknai parodi iklan produk Mastin dan persepsinya terhadap produk Mastin itu sendiri.

\section{Metode Penelitian}

Metodologi yang digunakan dalam penelitian ini adalah analisis resepsi dengan paradigma kualitatif deskriptif dan landasan teori yang akan digunakan adalah Elaboration Likelihood Model dan Hirearchy of Effects Model.

Responden dipilih berdasarkan kriteria apakah mereka mengkonsumsi teks parodi dan iklan mastin, serta menggunakan produk Mastin. Pada penelitian ini review yang dilakukan beauty blogger terhadap produk Mastin menjadi resepsi audiens yang akan dibahas serta pengguna Mastin di dunia nyata yang akan digunakan. Hal ini dikarenakan review yang dilakukan beauty blogger merupakan bentuk pemahaman audiens terhadap teks parodi dan produk "Mastin" sehingga memenuhi persyaratan kriteria di atas. Dalam penelitian kualitatif, pengumpulan data dihentikan apabila terjadi pengulangan (kejenuhan) informasi, sehingga tiga pemahaman audiens terhadap topik penelitian dirasa sudah cukup bagi peneliti.

Tahapan analisis resepsi mencakup dua tahap, yakni encoding dan decoding. Menurut Stuart Hall (2006: 11-12) bahwa suatu pesan adalah sebuah rangkaian peristiwa yang memiliki ideologi-ideologi. Dengan kata lain, setiap orang memiliki pemaknaan yang berbedabeda terhadap suatu peristiwa

Encoding adalah proses pemaknaan peristiwa oleh profesional media, hal ini dapat dimaknai pemaknaan peristiwa oleh peneliti. Selanjutnya decoding adalah cara khalayak melihat suatu peristiwa (ideologi). Di sini, khalayak tidak dihadapkan pada peristiwa sosial mentah, melainkan pada 'terjemahan' peristiwa sosial. Hall (1980: 136) berpendapat, bahwa sebagian besar teks adalah polisemi, namun pada umumnya produser teks dalam media biasanya sengaja membuat pesan yang bersifat preferred (dominant) dalam membaca teks. Preferred reading adalah cara khalayak membaca teks sebagaimana yang diinginkan oleh pembuat teks. Namun adakalanya khalayak tidak setuju atau misinterpretasi terhadap beberapa aspek tertentu. Cara memaknai teks seperti ini disebut dengan negotiated meaning. Apabila khalayak membaca suatu teks secara berseberangan, atau justru tidak peduli dengan isi teks, teknik membaca teks ini disebut dengan opposotional decoding (dalam Baran \& Davis, 2012: 258). Proses decoding ini selanjutnya akan dianalisa menggunakan pendekatan Elaboration Likelihood Model dan Hierarchy of Effects Model .

Elaboration Likelihood Model dikembangkan oleh Petty dan John Cacioppo. Elaboration Likelihood Model adalah teori persuasi karena teori ini mencoba untuk memprediksi kapan dan bagaimana audiens akan dan tidak akan terbujuk oleh pesan (dalam Griffin, 2012: 208-209). Teori ini mencoba untuk menjelaskan dengan cara berbeda di mana audiens mengevaluasi informasi yang diterima. Ada dua rute untuk mengolah pesan, rute periferal dan sentral. Rute periferal acapkali digeneralisasikan sebagai pemikiran kurang kritis dan tanpa pertimbangan, karena proses elaborasi tidak berlangsung secara kompleks. Sedangkan rute sentral digeneralisir sebagai cara berpikir kritis, hati-hati, banyak pertimbangan sehingga melibatkan motivasi dan kemampuan audiens.

Berdasarkan pengelompokkan rute pengolahan pesan yang digunakan audiens, maka selanjutnya peneliti akan meneliti sejauh mana efek persuasi bekerja dalam diri audiens menggunakan Hirearchy of Effect Model. Robert Lavidge dan Gary Steiner mengembangkan Hirearchy of Effect Model yang semula berkutat di ranah personal selling yang semula 
dikembangkan oleh St.Elmo Lewis ke ranah periklanan. Lavidge dan Gary berargumen bahwa setidaknya terdapat tujuh tahapan seseorang dalam memutuskan untuk membeli suatu produk yakni, unawareness, awareness, mengetahui, sikap terhadap produk dan merk, keinginan (desire), keyakinan (conviction), dan tahap pembelian (dalam Littlejohn dan Foss, 2009:19). Tujuh tahapan ini sendiri jika dikelompokkan membentuk tiga efek, yaitu efek kognitif, afektif (psikologis), dan behavioral (sosiologis). Efek kognitif yang terdiri dari ketidaksadaran (unawareness), kesadaran (awareness), pengetahuan (knowledge). Efek Afektif meliputi menyukai (liking), preferensi, dan keyakinan. Efek behavioral terjadi apabila audiens telah melakukan pembelian terhadap produk tersebut.

Brand awareness merupakan tahapan awal dari perilaku konsumsi audiens. Brand awareness dapat diraih apabila audiens sudah menyematkan atribut terhadap produk tersebut (Percy, 2008: 38). Brand awareness sendiri terdiri dari empat macam, yakni unaware, brand recognition, brand recall, dan top of mind. Brand recognition atau pengenalan suatu merk, merupakan tahapan audiens mengetahui eksistensi/keberadaan merk tertentu. Diikuti dengan brand recall, adanya atribut yang disematkan pada merk tersebut. Selanjutnya tahapan paling wahid dalam brand awareness adalah top of mind, dimana merk tersebut menguasai ingatan benak audiens dibanding produk sejenisnya (Shimp, 2007:35).

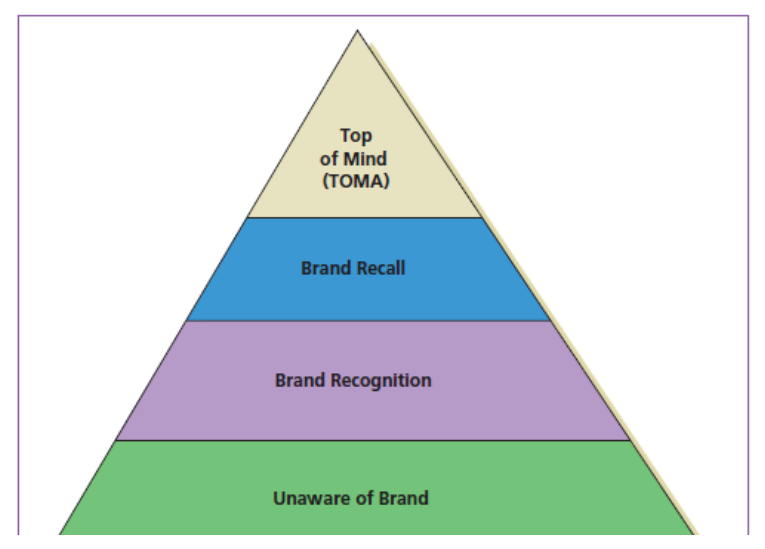

Gambar 3.2. Piramida Brand Awareness (David A.Aaker, 1990 dalam Shimp, 35: 2008)
Meraih suatu brand awareness merupakan tantangan tersendiri bagi produk baru, terutama produk-produk kesehatan herbal seperti Mastin. Melalui analisa resepsi audiens, peneliti ingin menggali seperti apa penafsiran audiens terhadap parodi iklan Mastin dan apa efeknya terhadap merk Mastin itu sendiri. Perbedaan latar belakang yang dimiliki oleh audiens menyebabkan penafsiran individu yang bermacam-macam. Khalayak memiliki peran aktif dan kekuasaan penuh atas penafsiran suatu teks.

Terkait dengan penelitian ini, apakah khalayak memilih memaknai parodi iklan "Mastin" selayaknya teoritisi kritis yang memandang bahwa parodi adalah bentuk suatu olokan terhadap produk tertentu, atau justru sebagai bentuk hiburan kreatif yang menjadikannya produk top of mind, atau justru mengacuhkan keduanya.

\section{Hasil Penelitian}

\subsection{Encoding}

Iklan Mastin adalah video yang tediri dari perpaduan antara animasi, stop motion, dan jingle. Kekuatan iklan ini berada pada lirik dan irama pada jingle lagu dalam iklan ini. Hal ini dikarenakan dalam parodi berbentuk video, jingle ini selalu disertakan sebagai latar musik. Lirik ini berbunyi:

"Kabar gembira untuk kita semua.

Kulit manggis, kini ada ekstraknya.

Mastin hadir, dan rawat tubuh kita.

Jadikan hari ini hari Mastin.

Tampil bersinar, membuatku bahagia.

Badan sehat, rahasia Mastin herbal.

Rahasia alam dari Indonesia.

Penuh pesona, pesona Mastin.

Mastin, good."

Pemutaran iklan yang berulang-ulang di berbagai televisi swasta menjadikan beberapa netizen membuat parodinya karena dirinya merasa lirik lagu tersebut menempel di kepala mereka. Ada beberapa yang menuliskan kunci 
nada dari jingle tersebut. Salah satu bentuk video parodi yang terkenal adalah video berjudul "Kabar Gembira Mbak Tien. Video yang bersetting di sebuah kelas perkuliahan ini bercerita tentang seorang mahasiswa berseragam putih-hitam yang terlambat masuk ke dalam kelas. Pada saat dimarahi oleh dosen karena keterlambatannya, mahasiswa tersebut justru menyela perkataan dosennya dengan berkata "tapi Pak, saya punya kabar gembira loh!" dan sang Dosen menjawabnya "kabar gembira?" dengan raut wajah bingung. Lalu tiba-tiba salah satu teman di kelasnya yang sudah duduk di kelas beranjak dari kursinya dan menyanyikan Jingle iklan Mastin dengan lirik pembuka berupa: "Kabar gembira untuk kita semua, kulit manggis kini ada ekstraknya" dan diikuti oleh teman-teman sekelas lainnya dengan menjadi penari latar.

Jingle yang mudah diingat, gerak gemulai aktor pria parodi, dan mimik wajah yang lucu menjadi daya tarik humor dari video. Video ini pun menyebar dengan cepat secara viral. Di luar video itu, terdapat berbagai video parodi lainnya yang muncul di Youtube seperti mengganti terjemahan anime, dan kartun dengan lirik jingle "Mastin". Sedangkan memé yang memanfaatkan lirik jingle "Mastin" ini marak untuk lelucon pada setiap kandidat calon presiden dalam Pemilu 2014 lalu.

\subsection{Decoding}

Menurut Informan pertama, ia merasa terhibur dengan iklan tersebut dan terkadang menggunakan kalimat "kabar gembira untuk kita semua" sebagai lelucon dalam kesehariannya. Selain itu, menurutnya tidak ada hal negatif dalam konten yang ada dalam parodi tersebut. Pada awalnya ia tidak begitu menaruh perhatian pada iklan televisi tersebut, namun dengan adanya video dan berbagai meme yang ada jadi mulai memperhatikan iklan tersebut. Bahkan saat ada iklan Mastin di televisi, ia menjadi ikut bersenandung. Pada suatu saat ia mengalami pembengkakan kelenjar getah bening, ia mencari referensi obat herbal alternatif dan menemukan bahwa kulit manggis berfungsi sebagai antioksidan. Saat itulah ia mengasosiasikan ekstra kulit manggis dengan merk Mastin.

Pada informan kedua, ia merasa jenuh dengan iklan tersebut dan sempat merasa terganggu karena penggunaan jargon kabar gembira untuk kita semua. Namun pada saat yang sama, ia menemukan banyaknya informasi terkait ekstrak kulit manggis bersamaan dengan tren tersebut dan menjadikannya tertarik menggunakan produk tersebut akibat coba-coba produk yang dianggapnya sedang naik daun. Latar belakang informan kedua sebagai beauty blogger belakangan ini merasa bahwa kulitnya sedang mengalami masalah dan mencari produk yang merawat dari dalam. Saat mencari informasi mengenai ekstra kulit manggis, kata pertama yang ia ketikkan dalam mesin pencarian google adalah Mastin. Pemilik blog dengan alamat lamourduciel.wordpress.com ini menemukan ternyata dengan dosis dan standar yang lebih tinggi, Mastin memiliki harga yang lebih terjangkau.

Informan ketiga memiliki latar belakang yang sama dengan informan kedua, yakni beauty blogger. Blog yang dimilikinya dengan alamat http://randomandquick.blogspot.co.id ini awalnya menertawakan dan menganggap sinis produk ekstrak kulit manggis bermerk Mastin ini akibat parodi dan iklan yang ada. Ia mengkonsumsi Mastin karena mencoba milik ayahnya, dan memiliki rasa tidak enak. Namun, pandangannya terhadap produk ini berbalik seratus delapan puluh derajat setelah menemukan informasi mengenai manfaatnya.

\section{Pembahasan}

Parodi iklan Mastin sasaran utamanya adalah iklan mastin, bukan produknya. Namun dengan gencarnya viral disertai dengan penayangan iklan di televisi menjadikan tren untuk beberapa saat. Berdasarkan informasi yang di dapat dari ketiga informan di atas, terdapat dua macam pemaknaan dalam membaca teks parodi iklan Mastin, yakni oppositional decoding pada informan pertama, dan dominant (preferred) 
reading pada informan kedua dan ketiga.

Jika ditinjau dari 9 level viral milik Silverman (2001: 32) maka viral parodi iklan Mastin ini masuk dalam kategori level 3 plus, sebab subyek viral secara aktif dan sukarela membicarakan TVC Mastin dengan rasa humor, bukan dengan perasaan kecewa atau marah. Bahkan jika awalnya merupakan wujud kekesalan karena terganggu dengan penayangan TVC Mastin, namun saat menjadi viral dia justru berubah menjadi sesuatu yang lucu dan bisa menjadi hiburan.

Hal ini terbukti dari penjaringan populasi viral TVC Mastin di situs gambar dan video humor 1cak.com, dimana terdapat ribuan posting tentang TVC Mastin disana. Karena yang menjadi obyek viral adalah tayangan iklan Mastin dan bukan produk Mastin maka viral yang berkembang tidak langsung berkaitan dengan khasiat yang ditawarkan Mastin. Sehingga saat khalayak menyaksikan parodi TVC Mastin, yang lebih dahulu mereka ingat adalah tayangan iklan Mastin bukan produk Mastin. Namun demikian saat pikiran khalayak mengingat tayangan TVC Mastin di saluran televisi, secara tidak langsung pasti mereka pasti juga akan terbayang produk Mastin.

Efek parodi iklan (secara tidak langsung terhadap produk Mastin) pada audiens setidaknya terbagi menjadi tiga macam efek sebagaimana dijabarkan dalam Hirearcy of Effect Model, yaitu: efek kognitif efek afektif, dan efek behavioral. Efek kognitif yang terdiri dari ketidaksadaran (unawareness), kesadaran (awareness), pengetahuan (knowledge). Efek Afektif meliputi menyukai (liking), preferensi, dan keyakinan. Efek behavioral terjadi apabila audiens telah melakukan pembelian terhadap produk tersebut.

Parodi iklan Mastin yang menyebar secara viral menjadikan masyarakat yang tidak tahu (unaware) menjadi sadar (aware) akan adanya keberadaan produk Mastin tersebut. Pengulangan adalah kekuatan utama viral, sehingga dapat mempercepat terbangunnya persepsi dalam benak khalayak yang terpapar (sengaja/tidak sengaja) viral tersebut. Pesan yang hadir secara berulang-ulang akan membuatnya masuk ke dalam benak sebagai daftar top of mind. Hal ini terbukti dari data yang diperoleh dari informan pertama yang menyatakan bahwa dirinya yang semula tidak mengetahui iklan produk tersebut menjadi memberi perhatian khusus hingga ikut menyanyi apabila ada iklan tersebut di televisi. Selain itu berdasarkan pengakuan informan kedua, saat ia mencari informasi mengenai ekstrak kulit manggis, nama Mastin yang tercetus di benaknya pertama kali.

Setelah mengetahui manfaat yang ada dalam ekstrak kulit manggis, maka muncullah ketertarikan (interest) akan produk Mastin. Selanjutnya dari ketertarikan tersebut, mereka membeli produk Mastin sebagai uji coba.

Penggunaan Mastin sebagai bentuk suplemen atau obat alternatif menjadikan orang berhati-hati dan melakukan pencarian informasi terlebih dahulu sebelum melakukan pembelian. Hal ini dikarenakan produk yang akan dibeli adalah produk yang terkait dengan kesehatan tubuh sehingga dibutuhkan elaborasi lebih lanjut.

Meminjam konsep dari Elaboration Likelihood Model (Richard Petty \& John Cacciopo dalam Griffin, 2012: 206)), bahwa terdapat dua rute dalam pemrosesan pesan. Kedua rute itu adalah rute periferal dan rute sentral. Rute periferal digunakan saat penerima pesan memiliki ketertarikan yang kurang atau justru tidak tertarik sama sekali terhadap pesan ataupun topiknya. Guna membangkitkan ketertarikan tersebut maka biasanya pesan yang menggunakan rute periferal dalam pemrosesannya mengandalkan pada sisi emosional dan bersifat permukaan. Sedangkan rute sentral dapat digunakan ketika penerima pesan memiliki motivasi dan kemampuan mengenai isi pesan dan topiknya. Motivasi untuk melakukan pemrosesan pesan ditentukan berbagai personal interest mengenai subjek dalam pesan. Menariknya, apabila penerima pesan memiliki sikap negatif yang kuat (opposite effect) dapat terjadi. Semakin menolak pesan, maka efek yang terjadi sebaliknya yakni 
sebagaimana yang diinginkan oleh isi pesan tersebut selayaknya kerja bumerang.

Berdasarkan temuan hasil penelitian di atas menunjukkan, bahwa parodi iklan Mastin yang bersifat humor-rute periferal-mengandalkan keatraktif-an pesan dapat mengubah pemrosesan pesan ke arah rute sentral yang dilakukan oleh audiens atau penerima pesan. Motivasi yang dimiliki oleh audiens untuk melakukan elaborasi lebih jauh terkait produk Mastin dilakukan berdasarkan relevansi personal seperti latar belakang informan I, dan II . Motivasi informan pertama dikarenakan dirinya mencari suplemen dan obat alternatif yang dapat membantu pemulihan dari pembengkakan kelenjar getah bening. Sedangkan motivasi informan ke-II dikarenakan ia membutuhkan suplemen untuk kulitnya yang bermasalah. Selain itu, pemrosesan sentral juga terjadi karena efek bumerang pada informan ke-III. Informan ke-III yang pada awalnya meragukan manfaat produk Mastin karena kehebohan parodi iklannya, menjadi tertarik dan melakukan elaborasi terhadap Mastin ketika ayahnya mengkonsumsi Mastin. Hal ini menunjukkan bahwa kemampuan (ability) untuk melakukan elaborasi meningkat ketika ada faktor familiaritas dengan subjek tersebut.

\section{Penutup}

\subsection{Simpulan}

Kritikus budaya mengidentifikasi dua dimensi parodi yang saling berdialektika. Pada satu sisi, parodi berisi humor dan permainan yang jenaka. Pada sisi lainnya, justru berisi olok-olokan atau hinaan (Rose dalam Bergh, et.al, 2011: 123). Akan tetapi sulit bagi peneliti untuk menentukan apakan audiens melihat kedua dimensi parodi tersebut, atau justru hanya melihat pada satu sisi saja. Berdasarkan hasil analisis resepsi terhadap tiga informan, informan pertama merasa terhibur; informan kedua merasa terganggu; dan informan ketiga justru meremehkan produk terkait. Pengelompokkan prefered reading dan oppositional reading diklasifikasi berdasarkan tujuan pembuat parodi. Tujuan awal pembuat parodi adalah mengolok- olok TVC Mastin, maka prefered (dominant) reading adalah penafsiran teks sesuai dengan yang diinginkan pembuat teks. Maka dari itu, peneliti mengelompokkan penafsiran informan pertama sebagai oppositional reading karena mengesampingkan sifat mengolok-olok TVC Mastin yang dilakukan oleh parodi tersebut, dan hanya melihat sisi hiburannya saja. Sedangkan penafsiran informan dua dan tiga dikelompokkan sebagai prefered reading karena penafsiran sesuai dengan tujuan dibuatnya teks parodi itu yaitu mengolok-olok sehingga muncul perasaan terganggu dan meremehkan produk.

Kedua cara audiens dalam membaca teks dapat dimanfaatkan bagi perencana komunikasi strategis untuk memaksimalkan efek persuasi dari iklan yang dibuat parodi. Hal ini karena audiens yang semula tidak tertarik dan terganggu oleh kehadiran parodi ataupun tren viral tersebut dapat berbalik menjadi tertarik selayaknya efek bumerang.

Berdasarkan analisa resepsi audiens di atas, dapat disimpulkan bahwa parodi iklan yang cenderung bersifat mengolok-olok iklan Mastin (parody attack) ini justru memberikan sumbangsih yang cukup tinggi bagi brand awareness "Mastin". Bukan hanya pada tahapan brand recognition saja, bahkan hingga melompat jauh ke tahapan paling tinggi dalam brand awareness, yaitu top of mind. Hal ini dikarenakan merk ekstrak kulit manggis yang pertama kali muncul di benak audiens adalah Mastin. Olokan kata-kata ganjil dalam lirik jinggle TVC "Mastin" berupa "kabar gembira untuk kita semua" yang melatarbelakangi parodi ini dan tidak jauh berbeda dengan yang ditafsirkan oleh audiens tidak lantas secara langsung memberikan citra buruk terhadap merk Mastin.

\subsection{Diskusi dan Saran}

Menyebarnya parodi iklan produk secara viral memang kadang tidak dapat diprediksi, dan apabila efeknya tidak terkelola dengan baik justru dapat menjatuhkan reputasi produk. Apabila sudah terlanjur produk atau iklan 
produk sudah menjadi viral yang bersifat negatif, efek negatif tersebut dapat diminimalisir dengan cara menyediakan informasi sebanyak mungkin di forum-forum internet dan menggunakan jasa blogger berpengunjung banyak untuk melakukan review untuk mengimbangi. Hal ini dikarenakan, secara sadar maupun tidak sadar audiens suatu saat akan mencari informasi tambahan terkait topik perbincangan yang viral tersebut.

\section{Daftar Pustaka}

Baran, Stanley J \& Davis, Denis K. (2012). Mass Communication Theory: Foundation, Ferment, and Future (6th Eds.) Boston, USA: Cengage Wadsworth Learning

Bergh, Bruce G.Vanden; Lee, Mira; Quiliam, Elizabeth. T; \& Hove, Thomas. The Multidimensional Nature and Brand Impact of User-Generated Ad Parodies in Social Media. International Journal of Advertising. Volume 30 (1), Halaman: 103-131

Griffin, Emmory. (2012). Communication Theory, a First Look at, 8th eds. New York, USA: McGraw Hill

Hall, Stuart. (1980). Encoding/Decoding dalam Stuart Hall; Dorothy Hobson, Andrew Lowe \& Paul Willis (eds.), Culture, Media, Language. UK: Center for Contemporary Cultural Studies

Irwansyah, Ade. Kabar Gembira, Parodi
Iklan Ekstrak Kulit Manggis Kocak dalam [http://showbiz.liputan6.com/ $\mathrm{read} / 2072893 /$ kabar-gembira-parodiiklan-ekstrak-kulit-manggis-kocak] diakses pada18 September 2015 pukul 10.23 WIB

Kurniawan, Novaria Fajar. (2015). Pengaruh Fenomena Iklan Televisi (TVC) Ekstrak Kulit Manggis Mastin Terhadap Preferensi Khalayak. Skripsi. Yogyakarta: Institut Seni Indonesia

Lou, Y. S., \& Wang, L. S. M. (2015). The Parody Attack Ad Influences the Ad Effect: Investigating the Moderating Effect of Need for Humor and Anti-Commercial Consumer Rebellion. Asian Journal of Business and Management, 3(1). Halaman: 11-23

Palmer, Jerry. (2004). Taking Humour Seriously. New York: Routledge

Percy, Larry. (2008). Strategic Intergrated Marketing Communication, Theory \& Practice. Oxford, UK: ButterworthHeinemann, Elsevier

Shimp, Terrence. A. (2007). Advertising, Promotion, and Other Aspects of Intergrated Marketing Communication, 7th edition. Chicago, USA: Thomson South-Western

Storey, John (penerjemah: Layli Rahmawati). (2006). Pengantar Komprehensif Teori dan Metode Cultural Studies dan Kajian Budaya Pop. Jalasutra: Yogyakarta

Silverman, George. (2001). The Secret of Word of Mouth. New York: AMAKOM 